\title{
OPTIMIZATION OF THE ROLES OF STAKEHOLDERS IN THE DEVELOPMENT OF SAMARES ECOTOURISM IN BIAK NUMFOR REGENCY
}

\author{
GUNARDI HAMDANI HAKIM ${ }^{1 *}$, TUTUT SUNARMINTO ${ }^{2)}$, NYOTO SANTOSO ${ }^{2)}$ \\ 1) Study Program of Ecotourism and Environmental Services Management, Faculty of Forestry, IPB Dramaga \\ Campus, Bogor 16680, Indonesia \\ 2) Department of Conservation of Forest Resource and Ecotourism, Faculty of Forestry, IPB Dramaga Campus, Bogor \\ 16680, Indonesia
}

*Email: gunardi.hamdani@gmail.com

Accepted 15 July 2020 / Approved 23 September 2020

\begin{abstract}
Samares is a coastal area in the villages of Sepse and Imndi in the East Biak District, Papua. Samares has several natural tourism objects that have the potential to be used for ecotourism activities. However, the current condition of the potency for ecotourism has not been well developed. Stakeholders participation was analyzed to identify and map the stakeholders' involvement and to formulate the role of stakeholders in the development of ecotourism in Samares. This research was conducted in Sepse Village from June to August 2019. Data were obtained from field observations, literature review, questionnaires and semi-directive interview. The data were analyzed using scoring technique to determine interest and influence of stakeholders. The results showed that there were 16 stakeholders involved in the development of ecotourism in Samares, which were categorized as subjects, key players, context setters, and crowds. Stakeholders consist of provincial and district government, NGO, community, and private entities. To enhance the development of ecotourism in Samares, increased collaboration of programs, synchronization and coordination that ecotourism management can be conducted unitedly and efficiently, increase stakeholders' participation, and increasing tourism promotion activities in Samares.
\end{abstract}

Keywords: cooperation, ecotourism, optimization, Samares, stakeholders' role.

\section{INTRODUCTION}

Ecotourism is a form of nature-based tourism that strives to be ecologically, economically, and sociocultural sustainable while providing opportunities for appreciating and learning about the natural environment or specific elements thereof (Weaver 2001). Ecotourism is characterized by involving conservation ethics, educational and environmental interpretation, emphasizing on ecological sustainability and minimizing potential impacts, as well as ensuring natural areas for ecotourism are preserved for the next generation (Roxana 2012).

Samares is one of the coastal areas in East Biak District with a high natural tourism potential. It is located in Sepse Village and Imndi Village, East Biak District, Biak Numfor Regency, Papua Province. Samares is developed into an ecotourism area since it has unique attractions. One of which is Telaga Opersnondi or known as the Blue Lagoon. The uniqueness of the lagoon is the crystal clear, blue, and brackish water. The locals people said that the depth is about 10-15 meters. In addition, another attraction is the white and clear sand of Samares Beach.

Some other ecotourism areas in East Biak District, particularly in Sepse Village and Imndi Village, that are less popular are teak plantation, Sepse Cave, Gunung Pintu Angin, bycyle tracking, and many more. East Biak District has many potential tourist objects to develop into the national level, making this district as the National Tourism Strategic Area (KSPN) listed on the Government Regulation of the Republic of Indonesia (PP RI) Number 50 of 2011 on "Master Plan of National Tourism Development 2010-2025".

Ecotourism potentials in Sepse Village and Imndi Village are not only unique, but also remain untouched (natural), making the objects have high aesthetical values. Other attraction is the fisherman around Sepse Village and Imndi Village who have tradition/culture in fishing known as "Snap Mor". Hence, Sepse Village and Imndi Village have their tourism potentials in the form of attractive beauty of nature and culture to build and develop into a tourist destination in Papua.

The main problem of ecotourism development in Samares lies on the poor coordination between stakeholders. Tourist object development in Samares requires a cooperation between tourism actors that is coordinated, sustainable and continuous. Alviya et al. (2016) stated that the role and participation of the stakeholders who have important position and influence on various activities will indicate a success in managing an area.

In optimizing the development of ecotourism, it needs the role of the stakeholders at the central, regional, and community levels (Hidayah et al. 2019). Based on PP Number 50 of 2011, to achieve changes in line with the objective of tourist destination development, it needs an 
institution as a continuous unit or cooperation between various parties, including the central government, regional government, private sector, and community. Reed et al. (2009) stated that in the process of decision-making and determining environmental policies at national and international levels, the participation or roles of the stakeholders are required.

An understanding of the existence of stakeholders is necessary to understand the roles and position of each stakeholder (Alviya et al. 2016). To create this understanding, a stakeholder analysis is needed to provide support in the implementation of ecotourism development in Samares. It is in line with Alviya et al. (2016), that the first step to identify the potential level and involvement of the stakeholders is by conducting a stakeholder analysis. The purpose of this paper is to analyze the relationship between the roles and cooperation of the stakeholders in ecotourism development in Samares.

\section{RESEARCH METHOD}

This study was conducted in Samares, Sepse Village and Imndi Village, East Biak District, Biak Numfor Regency. It was conducted for 3 months, from June-August 2019. The study was conducted using two approaches namely the qualitative and quantitative approaches. It was expected to describe the roles and influences of stakeholders in the development of ecotourism in Sepse Village and Imndi Village.

The data were collected from the results of field observation, literature study and interview with several communities (NGOs), government agencies and private groups involved in the development of ecotourism in Biak Numfor Regency. The interview was conducted using the semi-directive interview method with the respondents were guided in the discussion related to the research topic. The sampling technique was based on certain criteria in accordance with the research objectives (purposive sampling). The selection of respondent was based on the purposive sampling by considering that the respondents are ecotourism actors, both individuals and institutions who understand the problems at the research location.

The data were grouped into two: main data and supporting data. The main data were obtained through field observation and in-depth interview with the stakeholders. The supporting data were documents in the form of data on tourism, laws and regulations, including the Government Regulation Number 50 of 2011 on Master Plan of National Tourism Development 2010-2025, Regulation of the Minister of Home Affairs Number 33 of 2009 on Guidelines for Ecotourism Development in Regions.

The quantitative data are in the form of importance and influence criteria of the stakeholders implemented in a scoring system. The scoring model is referred to Siregar (2011) (Table 1).

The analysis used in this study is a stakeholder analysis by: 1) identifying stakeholders, 2) grouping and categorizing stakeholders based on the level of interest and influence of each stakeholder (Reed et al. 2009). The stakeholder analysis was processed using Microsoft Excel.

\section{RESULTS AND DISCUSSION}

\section{Stakeholder Identification}

Based on the results of identification, there are 16 stakeholders involved in the development of ecotourism in Samares, East Biak District. The stakeholders consist of five groups, they are the stakeholders from the government, community, NGO, university and private sector. Based on their functions, these stakeholders have their roles as presented in Table 2 .

Table 1 Quantitative measure of stakeholder's interest and roles.

\begin{tabular}{|c|c|c|c|}
\hline Score & Value & Criteria & Description \\
\hline \multicolumn{4}{|c|}{ Interest of stakeholders } \\
\hline 5 & $21-25$ & Very high & Very supportive to the development of ecotourism \\
\hline 4 & $16-20$ & High & Supportive to the development of ecotourism \\
\hline 3 & $11-15$ & Moderately high & Quite supportive to the development of ecotourism \\
\hline 2 & $6-10$ & Less high & Less supportive to the development of ecotourism \\
\hline 1 & $0-5$ & Low & Do not support the development of ecotourism \\
\hline \multicolumn{4}{|r|}{ Influence of stakeholders } \\
\hline 5 & $21-25$ & Very high & Very influential in the development of ecotourism \\
\hline 4 & $16-20$ & High & Influential in the development of ecotourism \\
\hline 3 & $11-15$ & Moderately high & Quite influential in the development of ecotourism \\
\hline 2 & $6-10$ & Less high & Less influential in the development of ecotourism \\
\hline 1 & $0-5$ & Low & Do not influence the development of ecotourism \\
\hline
\end{tabular}


One of the fundamental aspects in conducting a stakeholder analysis is to identify each stakeholder (Alviya et al. 2016). Stakeholder identification is needed to examine the general involvement of the stakeholders related to the development process of ecotourism in Samares. Stakeholder identification is also carried out to see an overview related to the involvement of the stakeholders in the management process of Ciliwung watershed (Alviya et al. 2016). Based on the identification above, it can be seen the parties and their roles in the development process of ecotourism in Samares. Each stakeholder has different strengths according to the function and optimization of the stakeholders in developing ecotourism.

Based on Table 2, it shows that there are 16 stakeholders involved in the development process of ecotourism in Samares. The Protection Forest Management Unit (KPHL) and the Tourism and Culture Office of Biak Numfor Regency are two implementing units that are fully responsible for managing various ecotourism activities in Samares, especially in protected forest environment.

Table 2 List of stakeholders and their roles in the development of ecotourism in Samares, East Biak District

\begin{tabular}{cl}
\hline No. & \multicolumn{1}{c}{ Stakeholders } \\
\hline & Government Element \\
1 & Protection Forest Management Unit \\
2 & Public Works Office \\
3 & Department of Tourism and Culture \\
4 & Center for Forest Biotechnology and \\
& Tree Improvement Research Yogya \\
5 & BPDASHL Memberano Jayapura \\
6 & Community Empowerment Agency \\
7 & East Biak District
\end{tabular}

- Determining the Blue Lagoon and Samares Beach as ecotourism areas.

- Preparing of Samares ecotourism management and development plan.

- Implementing technical operational activities to support forest management.

- Management of forest areas in regions, monitoring and evaluation.

- Implementing forest and land rehabilitation as well as soil and water conservation.

- Preparing of watershed and protection forest management plan.

- Preparing of technical plan for forest and land rehabilitation as well as soil and water conservation.

- Developing watershed and protection forest management model.

- Has an interest in developing ecotourism by supporting the facilities and infrastructure in ecotourism areas.

- Has an interest in promoting tourist objects by conducting promotion and training to the locals

$\begin{array}{cl} & \text { Community Element } \\ 8 & \text { Ecotourism Group (Samares) } \\ 9 & \text { (Sepse) Village } \\ 10 & \text { Byak Traditional Council } \\ 11 & \text { Imndi Village }\end{array}$

11 Imndi Village
- To convey community aspirations for the development of tourist objects in Sepse/ Samares village area.

- Has an interest in developing ecotourism potentials and preserving the environment in the region.

- Has an interest in developing ecotourism potentials and preserving the environment in the region.

- Has an interest in the protection and development of Sepse Village tourism object.

\begin{tabular}{|c|c|c|}
\hline $\begin{array}{l}12 \\
13\end{array}$ & $\begin{array}{l}\text { NGO Element } \\
\text { Rumsram Foundation } \\
\text { Samdhana Institute } \\
\text { Mnukwar }\end{array}$ & $\begin{array}{l}\text { - Fight for community aspirations in preserving forest. } \\
\text { - Provide knowledge about ecotourism concept. } \\
\text { - Developing potential objects to become ecotourism areas in the } \\
\text { region. }\end{array}$ \\
\hline 15 & $\begin{array}{l}\text { University Element } \\
\text { State University of Papua }\end{array}$ & Research and development \\
\hline 16 & $\begin{array}{l}\text { Private Element } \\
\text { PT. JSK Korea }\end{array}$ & $\begin{array}{l}\text { Has an interest in financing ecotourism development in Samares } \\
\text { (sponsorship) }\end{array}$ \\
\hline
\end{tabular}


Other stakeholders included in the government element are the Public Works Office, the Center for Forest Biotechnology and Tree Improvement Research Yogya, Center for Watershed Management and Protected Forest Management (BPDASHL) Memberano Jayapura, the Community Empowerment Agency, and East Biak District. Based on their roles, it can be seen that stakeholders from government element is responsible from planning, developing management model and implementing technical operation, rehabilitation, monitoring and evaluation. Meanwhile, BPDASHL Memberano Jayapura has a role as an institution or stakeholder that is responsible for managing watershed and protection forests.

The stakeholders coming from community element consists of Samares Ecotourism Group, Sepse Village, Imndi Village and Byak Traditional Council. While from the NGO elements are Rumsram
Foundation, Samdhana Institute and Mnukwar. Based on the roles, stakeholders coming from the community and NGO are responsible for empowering the local community, promoting ecotourism activities, and holding trainings for the community regarding the use, care and maintenance of ecotourism so that it remains sustainable and developing.

State University of Papua (UNIPA) and PT. JSK Korea is a stakeholder from higher education and private sector. UNIPA is responsible for research activities related to the development of ecotourism in KPHL area, forest utilization, and ecotourism carrying capacity. PT. JSK Korea plays a role in supporting the development of ecotourism activities in Samares financially. Broadly speaking, the implementation of stakeholders' involvement and interests in the development of ecotourism activities in Samares can be seen in Table 3.

Table 3 Involvement of each stakeholder in the development of ecotourism in Samares

\begin{tabular}{|c|c|c|c|c|c|}
\hline \multirow[b]{2}{*}{ Stakeholder } & \multicolumn{5}{|c|}{ Role } \\
\hline & $\begin{array}{l}\text { Policy } \\
\text { formulation }\end{array}$ & $\begin{array}{l}\text { Fund } \\
\text { support }\end{array}$ & $\begin{array}{l}\text { Research \& } \\
\text { advocation }\end{array}$ & $\begin{array}{l}\text { Technology } \\
\text { and training } \\
\text { facility }\end{array}$ & $\begin{array}{c}\text { Conservation \& infrastructure } \\
\text { maintenance }\end{array}$ \\
\hline $\begin{array}{l}\text { Protection Forest } \\
\text { Management Unit }\end{array}$ & ++ & ++ & ++ & ++ & ++ \\
\hline Public Works Office & - & - & - & - & ++ \\
\hline $\begin{array}{l}\text { Department of } \\
\text { Tourism and Culture }\end{array}$ & ++ & + & ++ & ++ & ++ \\
\hline $\begin{array}{l}\text { Center for Forest } \\
\text { Biotechnology and } \\
\text { Tree Improvement } \\
\text { Research Yogya }\end{array}$ & + & + & ++ & ++ & ++ \\
\hline $\begin{array}{l}\text { BPDASHL } \\
\text { Memberamo Jayapura }\end{array}$ & - & + & ++ & + & ++ \\
\hline $\begin{array}{l}\text { Community } \\
\text { Empowerment Agency }\end{array}$ & + & - & - & ++ & - \\
\hline East Biak District & ++ & + & - & ++ & ++ \\
\hline $\begin{array}{l}\text { The Samdhana } \\
\text { Institute }\end{array}$ & ++ & ++ & - & ++ & + \\
\hline Rumsam Foundation & + & + & - & ++ & + \\
\hline Mnukwar & - & + & - & ++ & + \\
\hline Sepse Village & + & - & - & - & + \\
\hline Imndi Village & + & - & - & - & + \\
\hline $\begin{array}{l}\text { Byak Traditional } \\
\text { Council }\end{array}$ & + & - & - & - & + \\
\hline $\begin{array}{l}\text { Ecotourism Group } \\
\text { (Samares) }\end{array}$ & + & - & - & ++ & ++ \\
\hline $\begin{array}{l}\text { State University of } \\
\text { Papua }\end{array}$ & - & - & ++ & - & + \\
\hline PT. JSK Korea & + & ++ & - & - & - \\
\hline
\end{tabular}

Description: $++=$ very involved; $+=$ less involved; - = not involved 
The roles of stakeholders were analyzed to describe the interests and roles of the stakeholders (Hidayah et al. 2019). Bryson (2003) states that the analysis of the roles of stakeholders is based on the interest of the stakeholders in a problem and the power (strength) of each stakeholder in influencing the problem. Sufficient understanding of the stakeholders on interest and authority will influence the success of a program (Hardiansyah 2012).

\section{Stakeholder Category}

Stakeholders are classified based on their level of interest and influence in the development of ecotourism in Samares. The level of interest of stakeholder is assessed from several aspects, that are stakeholders' involvement, benefits of ecotourism development, stakeholders' authority in ecotourism development, stakeholders' programs, and stakeholder's dependence. Meanwhile, the influence aspect is assessed from several indicators such as management rules or policies, roles and participation, ability to interact, authority in management, and capacity of the provided resources. The interest and influence aspects of the 16 stakeholders involved in the development of ecotourism in Samares are presented in Table 4 and Table 5.

The score of the level of importance and influence presented in Table 4 and Table 5 shows that each stakeholder has a different level of importance and influence. It is because each stakeholder has different main duties. Based on the results of the analysis, the stakeholders with high level of importance and influence are the stakeholders of KPHL and Disparbud Biak Numfor Regency. It shows that KPHL and Disparbud of Biak Numfor Regency have high responsibility for the management and development of ecotourism in Samares. The other 14 stakeholders have moderately high and less high level of importance according to the function of the stakeholders in the development of ecotourism in Samares.

Based on the score of the level of importance and influence above, the stakeholder can be classified into 4: subject, key player, context setter, and crowd. The stakeholders who are included in these categories are presented in Figure 1.

Table 4 Level of interest of stakeholders in the development of ecotourism in Samares

\begin{tabular}{|c|c|c|c|c|c|c|c|}
\hline \multirow{2}{*}{ No. } & \multirow{2}{*}{ Stakeholder } & \multicolumn{5}{|c|}{ Interest } & \multirow{2}{*}{ Total } \\
\hline & & $\mathrm{K} 1$ & $\mathrm{~K} 2$ & K3 & K4 & K5 & \\
\hline 1 & Protection Forest Management Unit (KPHL) & 5 & 5 & 5 & 3 & 4 & 22 \\
\hline 2 & Public Works Office & 4 & 4 & 3 & 2 & 2 & 15 \\
\hline 3 & Department of Tourism and Culture (Disparbud) & 5 & 4 & 4 & 4 & 2 & 19 \\
\hline 4 & $\begin{array}{l}\text { Center for Forest Biotechnology and Tree } \\
\text { Improvement Research Yogya }\end{array}$ & 3 & 3 & 2 & 2 & 1 & 11 \\
\hline 5 & BPDASHL Memberamo Jayapura & 3 & 2 & 2 & 2 & 1 & 10 \\
\hline 6 & Community Empowerment Agency & 3 & 4 & 2 & 2 & 2 & 13 \\
\hline 7 & East Biak District & 4 & 4 & 3 & 4 & 2 & 17 \\
\hline 8 & The Samdhana Institute & 4 & 4 & 3 & 3 & 2 & 16 \\
\hline 9 & Rumsam Foundation & 4 & 4 & 4 & 3 & 2 & 17 \\
\hline 10 & Mnukwar & 3 & 3 & 2 & 1 & 1 & 10 \\
\hline 11 & Sepse Village & 4 & 4 & 4 & 2 & 2 & 16 \\
\hline 12 & Imndi Village & 3 & 4 & 3 & 2 & 2 & 14 \\
\hline 13 & Byak Traditional Council & 3 & 4 & 2 & 2 & 2 & 13 \\
\hline 14 & Samares Ecotourism Group & 4 & 4 & 3 & 3 & 2 & 16 \\
\hline 15 & State University of Papua & 3 & 3 & 2 & 2 & 1 & 11 \\
\hline 16 & PT. JSK Korea & 4 & 4 & 3 & 2 & 1 & 14 \\
\hline
\end{tabular}

Description: 5: Very high; 4: High; 3: Moderately high; 2: Less high; 1: Low. K1= Stakeholders' involvement; K2= Benefits of ecotourism development; K3= Stakeholders' authority; K4= Stakeholders' program; K5= Stakeholders' dependence 
Table 5 Level of influence of stakeholder on ecotourism development in Sepse Village

\begin{tabular}{clcccccc}
\hline \multirow{2}{*}{ No. Stakeholders } & & \multicolumn{3}{c}{ Effect } & \multirow{2}{*}{ Total } \\
\cline { 3 - 5 } & & P1 & P2 & P3 & P4 & P5 & \\
\hline 1 & Protection Forest Management Unit (KPHL) & 5 & 5 & 5 & 2 & 4 & $\mathbf{2 1}$ \\
2 & Public Works Office & 4 & 3 & 3 & 2 & 2 & $\mathbf{1 4}$ \\
3 & Department of Tourism and Culture & 4 & 4 & 4 & 3 & 3 & $\mathbf{1 8}$ \\
& Center for Forest Biotechnology and Tree & 3 & 2 & 4 & 2 & 2 & $\mathbf{1 3}$ \\
4 & Improvement Research Yogya & & & & & & \\
5 & BPDASHL Memberamo Jayapura & 3 & 3 & 3 & 2 & 2 & $\mathbf{1 3}$ \\
6 & Community Empowerment Agency & 3 & 3 & 3 & 2 & 1 & $\mathbf{1 2}$ \\
7 & East Biak District & 4 & 4 & 4 & 2 & 2 & $\mathbf{1 6}$ \\
8 & The Samdhana Institute & 3 & 3 & 4 & 2 & 4 & $\mathbf{1 6}$ \\
9 & Rumsam Foundation & 3 & 3 & 4 & 2 & 3 & $\mathbf{1 5}$ \\
10 & Mnukwar & 2 & 2 & 3 & 1 & 3 & $\mathbf{1 1}$ \\
11 & Sepse Village & 3 & 3 & 4 & 1 & 2 & $\mathbf{1 3}$ \\
12 & Imndi Village & 3 & 3 & 4 & 1 & 3 & $\mathbf{1 4}$ \\
13 & Byak Traditional Council & 3 & 4 & 3 & 3 & 3 & $\mathbf{1 6}$ \\
14 & Samares Ecotourism Group & 4 & 4 & 3 & 3 & 3 & $\mathbf{1 7}$ \\
15 & State University of Papua & 3 & 2 & 3 & 2 & 2 & $\mathbf{1 2}$ \\
16 & PT. JSK Korea & 3 & 3 & 4 & 1 & 2 & $\mathbf{1 3}$ \\
\hline
\end{tabular}

Description: 5: Very high; 4: High; 3: Moderately high; 2: Less high; 1: Low. P1= Stakeholders' ability; P2= Contribution of facilities provided by stakeholders; P3= Institutional/ HR capacity assigned by stakeholders; P4= Budget support; P5= Stakeholders' ability in implementing ecotourism development

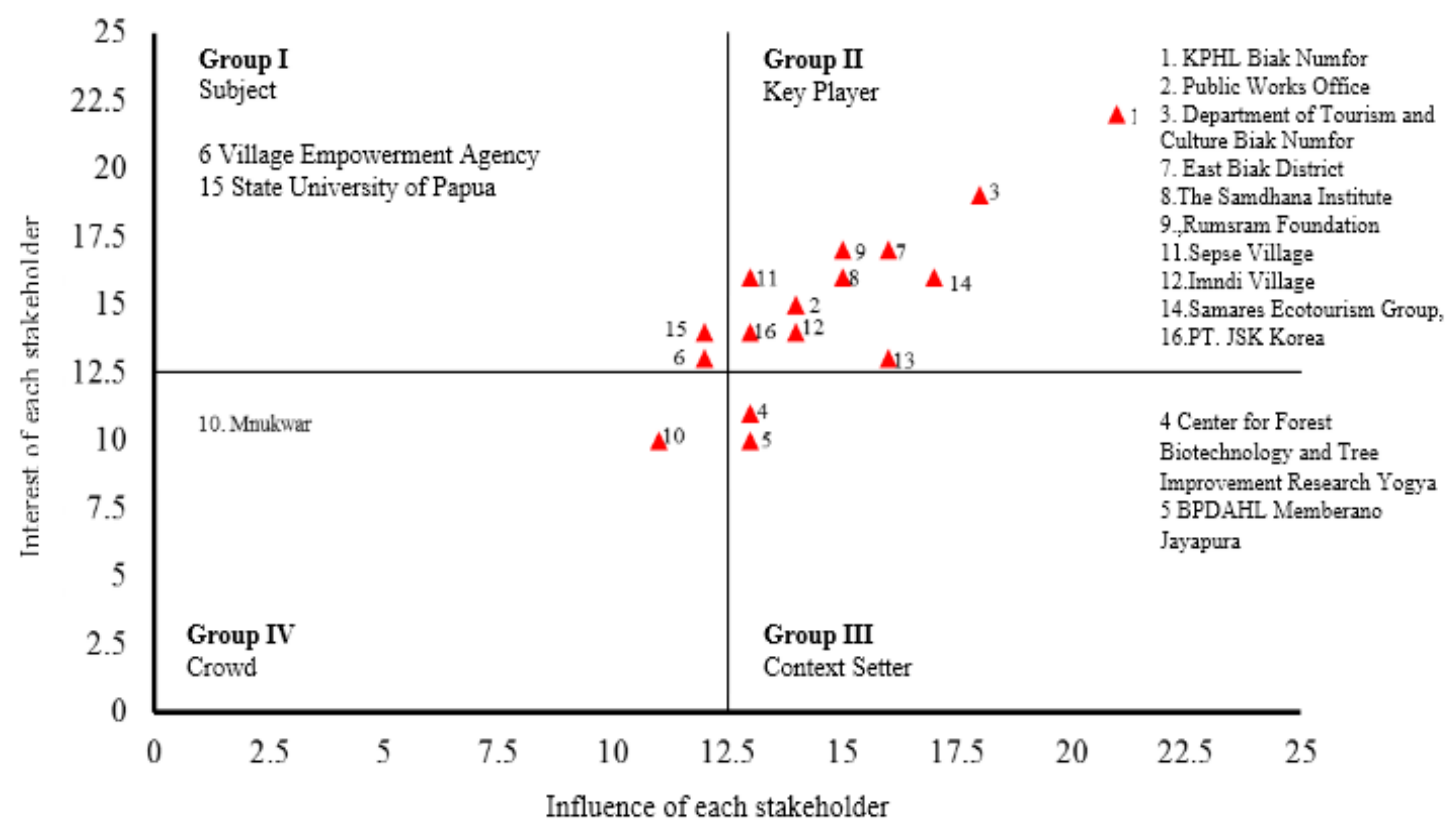

Figure 1 Classification matrix of stakeholder 
The subject group is stakeholders who have high interest, but low authority. The stakeholder who fall into this category are Village Empowerment Agency and State University of Papua. This is because these two stakeholders have high concern on the development of ecotourism in Samares, but they do not have strong power to carry out the programs directly. According to Alviya et al. (2016), parties included in the subject category are usually due to lack of human resources, not stated in the management main duties and function, and low resource capacity.

The key player is the stakeholder who has a high concern and power among the stakeholders. The stakeholders included in the key player category are KPHL Biak Numfor, Public Works Office, Disparbud Biak Numfor, East Biak District, The Samdhana Institute, Rumsram Foundation, Sepse Village, Imndi Village, Samares Ecotourism Group, and PT. JSK Korea. It is because these stakeholders have great roles in the development process of ecotourism in Samares. The key player group has sufficient resources to carry out various ecotourism management and development activities starting from the planning, activities implementation, monitoring and evaluation stages. In addition, KPHL and Disparbud have high interest and influence because the ecotourism area in Sepse Village is located in the protection forest area. These parties have the power to influence others by relying on their own knowledge, network, the power to influence others, and the authority to make decisions.

Context setter group is the stakeholder who has the ability to influence other stakeholders lain to participate in implementing and supporting the management and development of ecotourism in the region. The stakeholders who fall into this category are the Center for Forest Biotechnology and Tree Improvement Research Yogya and BPDASHL Memberano Jayapura.

Crowd group is the stakeholder who has a low level of importance and influence on the development of ecotourism in Samares. The stakeholder who falls into this category is Mnukwar. According to Hernawan et al. (2018), the stakeholder included in this crowd group needs to be reconsidered to be involved in the decisionmaking according to their respective capacities.

The development of Samares ecotourism area requires a high level of cooperation between stakeholders from the central government, regional, private sector as well as the community. It means cooperation between two or more parties who provide mutual benefits and have goals that can work together in developing ecotourism activities. The collaboration between stakeholders is presented in Table 6.

Table 6 Collaboration between stakeholders

\begin{tabular}{|c|c|c|}
\hline No & Stakeholders & Description \\
\hline 1 & $\mathrm{~A}_{1,3} \mathrm{~F} / \mathrm{P} / \mathrm{K}$ & $\begin{array}{l}\text { KPHL and Disparbud collaborate in programs for the development of } \\
\text { ecotourism in the protection forest areas. The form of collaboration includes } \\
\text { the use of protection forest areas as market-worthy tourism products } \\
\text { containing education, learning and recreation; empowerment of communities } \\
\text { around the area; cooperation in collecting data on tourism objects for the } \\
\text { preparation of site design based on a predetermined zoning system. }\end{array}$ \\
\hline 2 & $\mathrm{~A}_{1,3} \mathrm{~W}$ & $\begin{array}{l}\text { KPHL and Disparbud collaborate in events, regional and national tourism } \\
\text { exhibitions, such as Muara Wampasi Festival and Tradisi Gebyar Wisata } \\
\text { Budaya Nusantara. }\end{array}$ \\
\hline 3 & $\mathrm{~A}_{1,12} \mathrm{P} / \mathrm{M}$ & $\begin{array}{l}\text { KPHL collaborates with BPDASHL Memberamo Jayapura in forest } \\
\text { management and forest rehabilitation. }\end{array}$ \\
\hline 4 & $\mathrm{~A}_{1,8} \mathrm{~F}$ & $\begin{array}{l}\text { The collaboration between KPHL and Samdhana Institute was marked by the } \\
\text { signing of a cooperation agreement on January } 2011 \text {. One of the points in the } \\
\text { agreement is the development of environmental ecotourism services by } \\
\text { designing natural tourism management sites in KPHL areas. }\end{array}$ \\
\hline 5 & $\mathrm{~A}_{1,13} \mathrm{P}$ & $\begin{array}{l}\text { KPHL together with the Byak Traditional Council have made a Customary } \\
\text { Agreement on July } 6,2010 \text { regarding the prohibition of taking eucalyptus in } \\
\text { Biak area, as a good cooperation on May 12, } 2012 \text { KPHL based on } \\
\text { community reports that secured } 4 \text { agarwood thieves. }\end{array}$ \\
\hline 6 & $\mathrm{~A}_{1(3,8,9,10)} \mathrm{K}$ & $\begin{array}{l}\text { KPHL together with Disparbud collaborated with Samdhana, Rumsram } \\
\text { Foundation and Mnukwar in holding a Workshop on Natural Tourism } \\
\text { Business on April 23, } 2013 \text {. }\end{array}$ \\
\hline 7 & $\mathrm{~A}_{6,11} \mathrm{M}$ & $\begin{array}{l}\text { BPMK and Sepse Village officials collaborate to provide community } \\
\text { assistance in improving the community's ability to seize business } \\
\text { opportunities for increasing welfare. }\end{array}$ \\
\hline
\end{tabular}




\begin{tabular}{ccl}
\hline No & Stakeholders & \multicolumn{1}{c}{ Description } \\
\hline 8 & $\mathrm{~A}_{3,(1,9,8)} \mathrm{P}$ & Disparbud, KPHL, Rumsram and Samdhana Foundation collaborate in an \\
& & ecotourism working group forum based on the Decree of the Regent of Biak \\
& Regency Numfor number 224 of 2014. Its duties include preparing an \\
& academic draft for Raperda on tourism, improving RIPPDA draft and specific \\
& tourism development plan.
\end{tabular}

$9 \quad \mathrm{~A}_{3,(1,7,8,11,12,14)} \mathrm{P}$

$10 \quad \mathrm{~A}_{1,4} \mathrm{~W}$

$11 \quad \mathrm{~A}_{1,15} \mathrm{~K}$

$12 \quad \mathrm{~A}_{9,8} \mathrm{M}$

$13 \mathrm{~A} 1,3,2 \mathrm{~W}$

$14 \quad \mathrm{~A}(1,3), 16 \mathrm{M}$

$15 \quad \mathrm{~A}_{3(1,10)} \mathrm{M}$

For the development of natural tourism in KPHL area, on early October 2010, an MoU was carried out between Disparbud, KPHL, East Biak District, Samdhana, the Heads of Sepse Village and Imndi Village, and Ecotourism Group (Samares) which contained cooperation in the management of ecotourism in Sepse Village and its surroundings, by making improvements such as providing support for homestay facilities, bedding and training in tourism. On September 29, 2012, Sepse Village was launched as a Tourist Village.

KPHL collaborated with the Center for Forest Biotechnology and Tree Improvement Research Yogya in the development of eucalyptus trees that have been planted since 2016. It is expected that technology intervention from the center will continue to be provided to Biak Numfor KPHL, so that the prospect of developing eucalyptus continues to be developed.

KPHL collaborated with Unipa in conducting research, especially conservation programs around the protection forest areas.

Rumsram established a collaboration with Samdhana regarding the provision of financial assistance for conservation and ecotourism activities. These activities include: Knowledge sharing facilitation program for communitybased ecotourism development and tourism potential assessment program for Sepse village area.

KPHL, Disparbud and Public Works Office work together to improve facilities and infrastructure in the ecotourism areas. The cooperation is to improve road access to tourist destinations. In addition, toilet facilities and guard posts at the entrance have been provided for visitors, especially those that are widely used on Saturday and Sunday.

KPHL and Disparbud in collaboration with PT. JSK Korea in funding to develop Samares ecotourism and development of petung bamboo (Dendrocalamus asper) which can be developed into bioenergy/ pellets, building construction materials, furniture, textile raw materials and flooring. Currently, the land under development as a demonstration plot for bamboo seedlings is $77 \mathrm{Ha}$.

KPHL, Disparbud and Mnukwar collaborated to organize guiding trainings according to the competency standards issued by the Ministry of Tourism and Creative Economy on 6-22 December 2011.

Description: 1: KPHL; 2: Public Works Service; 3: Disparbud; 4: Center for Forest Biotechnology and Tree Improvement Research Yogya; 5: BPDASHL Memberamo Jayapura; 6: Community Empowerment Agency (BPMK); 7: East Biak District; 8; The Samdhana Institute; 9: Rumsram Foundation; 10: Mnukwar; 11: Sepse Village; 12: Imndi Village; 13: Byak Traditional Council; 14: Samares Ecotourism Group; 15: State University of Papua; 16: PT. JSK Korea; A: Cooperation, F: Flora and fauna preservation, K: Strengthening of institution, M: Community empowerment, P: Protection of area, and W: Development of natural tourism.

\section{CONCLUSION}

The stakeholders involved in the development of ecotourism in Samares consist of four categories: key player (KPHL Biak Numfor, Public Works Office, Disparbud Biak Numfor, East Biak District, The
Samdhana Institute, Rumsram Foundation, Sepse Village, Imndi Village, Samares Ecotourism Group, and PT. JSK Korea), subject (Community Empowerment Agency and State University of Papua), context setter (Center for Forest Biotechnology and Tree Improvement Research 
Yogya and BPDASHL Memberano Jayapura), and crowd (Mnukwar). Key player has a high influence and importance in the development of ecotourism in Samares. Key players must work collaboratively by involving and inviting stakeholders in the group of subject, context setter, and crowd.

The collaboration between stakeholders in the development of ecotourism in Samares tends to be weak, especially those that involve local communities, so the roles and attention of local communities to ecotourism is still low. In developing ecotourism in Samares, a binding cooperation between stakeholders is needed, increasing program collaboration, synchronization, and coordination so that ecotourism management can be carried out in an integrated and well-programmed manner. Furthermore, it needs to building ecotourism awareness through the Samares Ecotourism Group, empowering the community to take advantage of each tourist attraction in improving the economy, increasing tourism object promotion activities from the Disparbud website and other government websites.

\section{REFERENCES}

Alviya I, Suryandari EY, Maryani R, Muttaqin MZ. 2016. Meningkatkan peran pemangku kepentingan dalam pengelolaan wilayah hulu Daerah Aliran Sungai Ciliwung. Jurnal Penelitian Sosial dan Ekonomi Kehutanan. 13(2): 121-134.

Bryson JM. 2003. What to do when stakeholders matter: A guide to stakeholder identification, analysis, and influence techniques. A paper presented at the London School of Economics and Political Science. London: University of Minnesota.
Hardiansyah G. 2012. Analisis peran berbagai stakeholder dalam menyongsong era pembangunan $\mathrm{KPH}$ di Kabupaten Ketapang. Jurnal EKSOS. 8(3): 186194.

Hernawan E, Basuni S, Masy'ud B, Kusrini MD. 2018. Partisipasi stakeholder dalam konservasi tuntong laut di Kabupaten Aceh Tamiang. Media Konservasi. 23(3): 226-235.

Hidayah NA, Hutagulung SS, Hermawan D. 2019. Analisis peran stakeholder dalam pengembangan wisata talang air peninggalan kolonial Belanda di Kelurahan Pajaresuk Kabupaten Pringsewu. Jurnal Ilmu Administrasi Publik. 7(1): 55-71.

Peraturan Pemerintah Nomor 50 Tahun 2011 Tentang Rencana Induk Pembangunan Kepariwisataan Nasional Tahun 2010-2025.

Reed SM, A Graves, N Dandy, H Posthumus, K Huback, J Morris, Ch Prell,CH Quin, LC Stringer. 2009. Who's in and why? A typology of stakeholder analysis methods for natural resource management. Journal of Environmental Management. 30: 1-17.

Roxana DM. 2012. Considerations about ecotourism and nature-based tourism - realities and perspectives. International Journal of Academic Research in Economics and Management Sciences. 1(5): 215221.

Siregar M. 2011. Peranan stakeholder terhadap pengembangan ekowisata di Taman Nasional Teluk Cenderawasih Kabupaten Teluk Wondama Provinsi Papua Barat [tesis]. Bogor: Institut Pertanian Bogor.

Weaver DB. 2001. Ecotourism as mass tourism: Contradiction or reality?. Cornell Hotel and Restaurant Administration Quarterly. 42(2):104112. 